\title{
Physicochemical indicators of land degradation in Burkina Faso
}

\author{
Jérôme T. YAMEOGO ${ }^{1 *}$, Zézouma SANON ${ }^{2}$, Boubacar M. MOUSSA ${ }^{3}$, Irénée SOMDA ${ }^{1}$, \\ Anne M. LYKKE ${ }^{4}$ and Jørgen A. AXELSEN ${ }^{4}$ \\ ${ }^{1}$ University of Nazi Boni, Rural Development Institute, Bobo-Dioulasso, Burkina Faso. \\ ${ }^{2}$ National Center of Scientific and Technological Research, Department of Environment and Forests, Institute \\ of Environment and Agricultural Research, Ouagadougou, Burkina Faso. \\ ${ }^{3}$ University of Diffa, Department of Plant Production, Faculty of Agronomic Sciences, Diffa, Niger. \\ ${ }^{4}$ Aarhus University, Department of Bioscience, Vejlsфvej 25, 8600 Silkeborg, Denmark. \\ *Corresponding author; E-mail: jerotega@yahoo.fr
}

\begin{abstract}
Desertification and land degradation affect the livelihood of a large number of people in the drier areas of the world, but there is no generally accepted scale on which the degree of degradation should be measured. However, researchers work to find indicators of degradation. In this paper, we have investigated a number of soil-physicochemical parameters that are related to degradation in order to identify some of them that can be used as degradation indicators. Land use was assessed via a Landsat 7 ETM+ satellite image. Soil samples were taken and analysed. The results showed that high sand content and $\mathrm{C} / \mathrm{N}$ values may be used as indicators of degradation, and high contents/values of $\mathrm{C}, \mathrm{N}$, available-K and especially soil cation exchange capacity (CEC) may be used as indicators of no or weak degradation. The CEC variable showed the steepest gradient in relation to land use, and this parameter may be the most useful soil physicochemical degradation indicator.

(C) 2019 International Formulae Group. All rights reserved.
\end{abstract}

Keywords: Africa, desertification, land use, organic matter, soil fertility.

\section{INTRODUCTION}

Land degradation is a composite term; it has no single readily identifiable feature, but instead describes how one or more of the land resources (e.g. soil and/or vegetation) have changed for the worse. There is, consequently, no precise way of measuring degradation. In an idealised world, degradation should be measured by two identical investigations of vegetation and/or soil physicochemical parameters carried out with an interval of many years (FAO, 2004). Such investigations could reveal if a degradation process was going on. However, in most cases there is no investigation from the past for comparison, and therefore scientists have been trying to identify parameters that can indicate if and to which extend an area has suffered from degradation. Concerning vegetation parameters, particular species that are associated with low species diversity have been suggested as indicators of desertification (Schmidt \& Zizka, 2014). Concerning soil erosion risk, the average rate of water erosion has been used (Febles et al., 2009). Concerning physicochemical soil parameters carbon and nitrogen content (Traoré et al., 2015), soil texture, organic matter, bulk 
density, and $\mathrm{pH}$ (Tebebu et al., 2017) have been used or suggested as indicators of degradation. However, so far, there is no consensus in the scientific literature on which indicators to use for estimating the extent of land degradation.

Degraded land is frequently regarded as having low soil fertility and many investigations of degradation are concerned with the loss of fertility of arable land (Febles et al., 2009). Therefore, it is an obvious possibility to use fertility indicators as indicators of degradation as well, such as the content of organic matter, soil exchange capacity (Khaledian et al., 2017), nitrogen, phosphorous and other nutrients. The balance between soil organic matter (SOM) and fine soil particles (SOM/(silt+clay)) has also been suggested in agricultural systems (Quiroga et al., 2006).

One of the problems related to defining degradation indicators is the definition of level of degradation, as there is no welldefined way of measuring degradation (Febles et al., 2009). One way of measuring land degradation could also be to relate a measured condition to a baseline, which in principle should be the vegetation formation found in untouched vegetation. A ranking of areas in relation to degradation could be made in terms of how different they are from the optimal vegetation type under the present climate conditions.

This paper aimed at identifying some soil physicochemical parameters that can be used as degradation indicators using different land use as a scale of degradation.

\section{MATERIALS AND METHODS \\ Study area}

The study was carried out in the Koulbi Forest and surroundings in south-western Burkina Faso. The area includes wellpreserved natural vegetation as well as different land use types within a short distance. The forest is located between $2^{\circ} 58^{\prime}$ $2^{\circ} 42^{\prime} \mathrm{W}$ and $9^{\circ} 29^{\prime}-9^{\circ} 45^{\prime} \mathrm{N}$. The area has a south-sudanian climate with two seasons, a rainy season from June to September and a dry season from October to May (Fontes \&
Guinko, 1995). The annual rainfall ranges from 900 to $1000 \mathrm{~mm}$. The average annual temperature is $29{ }^{\circ} \mathrm{C}$ (Kaboré et al., 2015). Soils are mainly tropical ferruginous. The topography is mostly flat with some elevations ranging from 220 to $325 \mathrm{~m}$ altitude.

\section{Land use}

Land use was assessed via a Landsat 7 ETM+ satellite image 27/11/2010 at the beginning of the project. It was downloaded from the United States Geological Survey's (USGS) website: "http://www.earthexplorer.usgs.gov/". ENVI 5.1 software was used to correct atmospheric and radiometric effects and to generate the false colour composite with bands 4, 3, 2 combinations in order to identify and discriminate soil surface conditions such as water, soil and vegetation. Supervised classification and maximum likelihood algorithm was performed to the image (Tankoano et al., 2016; Dimobe et al., 2017; Gbedahi et al., 2019) in order to identify different land-cover classes. Two hundred and forty-nine (249) field points were considered using a Global Positioning System (GPS) in different land use classes. One part (126 points) of those field points were used to extract training areas or regions of interest and the remaining (123 points) were used on postclassification processing to assess classification accuracy, overall accuracy and Kappa index. Vectorized data were processed with ArcGis 10.2 software.

\section{Soil sampling}

Soil sampling points were selected to cover the most common land use types. In total 25 sampling sites: three in woodland, ten in tree savanna, eight in shrub savanna, two in fallow and two in fields. A sample consisted of five subsamples taken with a soil auger (diameter $5 \mathrm{~cm}$ ), and these subsamples were mixed to form a composite sample $(1 \mathrm{~kg}$ of soil). Samples were taken at $0-10 \mathrm{~cm}$ and $10-$ $20 \mathrm{~cm}$ depths for each of 25 sites in May 2014. The number of sample from each land use type was proportional to its area. The gallery forests were not taken into account, as 
they were found under different topography and soil conditions.

\section{Soil analysis}

Soil texture analyses were undertaken using the pipette method (Loveland \& Whalley, 1991). The $\mathrm{pH}$ was analyzed by the $\mathrm{pH}$-water method using a 1:2.5 soil/water suspension following the procedure described by Sahilemedhin \& Taye (2000). The carbon (C) content was analysed by the WalkleyBlack method and converted to soil organic matter (SOM) with the conversion factor of 1.72 (Mylavarapu, 2015). Total nitrogen (N) was analysed by the Kjeldahl method (Bremner, 1965), total exchangeable phosphorus (Exc-P) by the Bray I method (van Reeuwijk, 2002), and available potassium (avail-K) by atomic absorption spectrometry after extraction of ammonium acetate-extractable cations (BUNASOLS, 1987). The exchangeable base cation $\left(\mathrm{Ca}^{2+}\right.$, $\mathrm{Mg}^{2+}, \mathrm{K}^{+}$and $\left.\mathrm{Na}^{+}\right)$contents and soil cation exchange capacity (CEC) were analyzed using inductively coupled plasma spectrometry (BUNASOLS, 1987). Sum of exchangeable base cation (SBE) is the sum of the contents of cations $\mathrm{Ca}^{2+}, \mathrm{Mg}^{2+}, \mathrm{K}^{+}$and $\mathrm{Na}^{+}$. Soil saturation rate $(\mathrm{V})$ was calculated by the ratio SBE/CEC.

\section{Statistical analysis}

The data were analysed using analysis of variance (ANOVA). Fisher's LSD tests were used for post hoc comparisons at 5\% significance level. A principal component analysis (PCA) was carried out to assess the relationships between soil physicochemical parameters and land use types. The PCA was based on a correlation matrix of all physiochemical parameters and vegetation types were added as a secondary factor. The analysis was done using $\mathrm{R}$ ( $\mathrm{R}$ development Core T., 2010).

\section{RESULTS \\ Land use}

The land use map (Figure 1) shows six thematic classes. These classes were: gallery forest $(2.2 \%)$, woodland $(7.5 \%)$, tree savanna
(51.2\%) and shrub savanna (31.3\%), fallow $(5.5 \%)$ and fields $(2.3 \%)$.

\section{Soil physical characteristics}

Clay, silt and sand fractions were significantly different among land use types (Table 1). Woodland and tree savanna had significantly higher clay contents than field/fallow in the two depths. Silt content was significantly higher in tree savanna than in field/fallow in the 0-10 cm depth. In the 10-20 $\mathrm{cm}$ depth, both woodland and tree savanna were significantly higher than field/fallow. Sand content was significantly higher in field/fallow than in woodland and tree savanna for both depths.

\section{Soil chemical characteristics}

Significant differences were found among land use types for soil chemical parameters C, SOM, N, SBE and CEC $(\mathrm{p}<0.01)$ in the two depths; $0-10 \mathrm{~cm}$ (Table 2) and $10-20 \mathrm{~cm}$ (Table 3 ). Their values were higher in woodland and tree savanna than in field/fallow. The content of avail-K was significantly higher $(\mathrm{p}<0.01)$ in woodland and tree savanna only in the $0-10 \mathrm{~cm}$ depth. Furthermore, the $\mathrm{C} / \mathrm{N}$ ratio was highly different $(p<0.01)$ between land use types being higher in shrub savanna and field/fallow than in woodland and tree savanna. The $\mathrm{C} / \mathrm{N}$ ratio was over 15 in shrub savanna and field/fallow. There were no significant differences between the land use types for Exc-P and V.

The PCA diagram provides an overview of soil land-use types based on soil physicochemical parameters. The first axis accounted for $54 \%$ of the total variance and the second axis for $13 \%$ (Figure 2). There is a highly positive correlation between soil parameters such as $\mathrm{N}(\mathrm{r}=0.94)$, CEC $(\mathrm{r}=$ $0.93)$, SBE $(r=0.90), C(r=0.89)$, clay $(r=$ $0.88)$ and the first axis. These variables were characteristic of the woodland and the tree savanna. In contrast sand $(r=-0.93)$ and $\mathrm{C} / \mathrm{N}$ ratio $(\mathrm{r}=-0.71)$ were significantly and negatively correlated to the first axis. These soil parameters were characteristic for shrub savanna and field/fallow. 


\section{Indicators}

The highly negative correlation between sand, $\mathrm{C} / \mathrm{N}$ and the first axis, seen in combination with the clear separation of field/fallow on one side and woodland and tree savanna on the other (Figure 2b), suggests that these two parameters may be used as degradation indicators. Similarly, the positive correlation between N, CEC, SBE, C, organic matter, silt and clay, suggest that some of these parameters may be used as indicators of low levels of degradation. There is a clear tendency of high values of $\mathrm{C}$, organic matter, $\mathrm{N}$, avail-K, CEC, SBE in woodland and tree savanna, medium values in shrub savanna and low values in field/fallow (Figure 3). Of these parameters CEC show a very marked gradient with values ranging from three $\mathrm{Cmol}^{+} \mathrm{Kg}^{-1}$ soil in field/fallow to 22 in woodland and tree savanna. Concerning woodland and tree savanna it is clear that they show very similar values for all measured parameters. Some of the parameters suggested as fertility indicators such as $\mathrm{C}$ and $\mathrm{N}$ show differences of a factor two or three, whereas SOM/(silt+clay) show a relatively weak response to land use with less than a factor two between the largest and the lowest value.

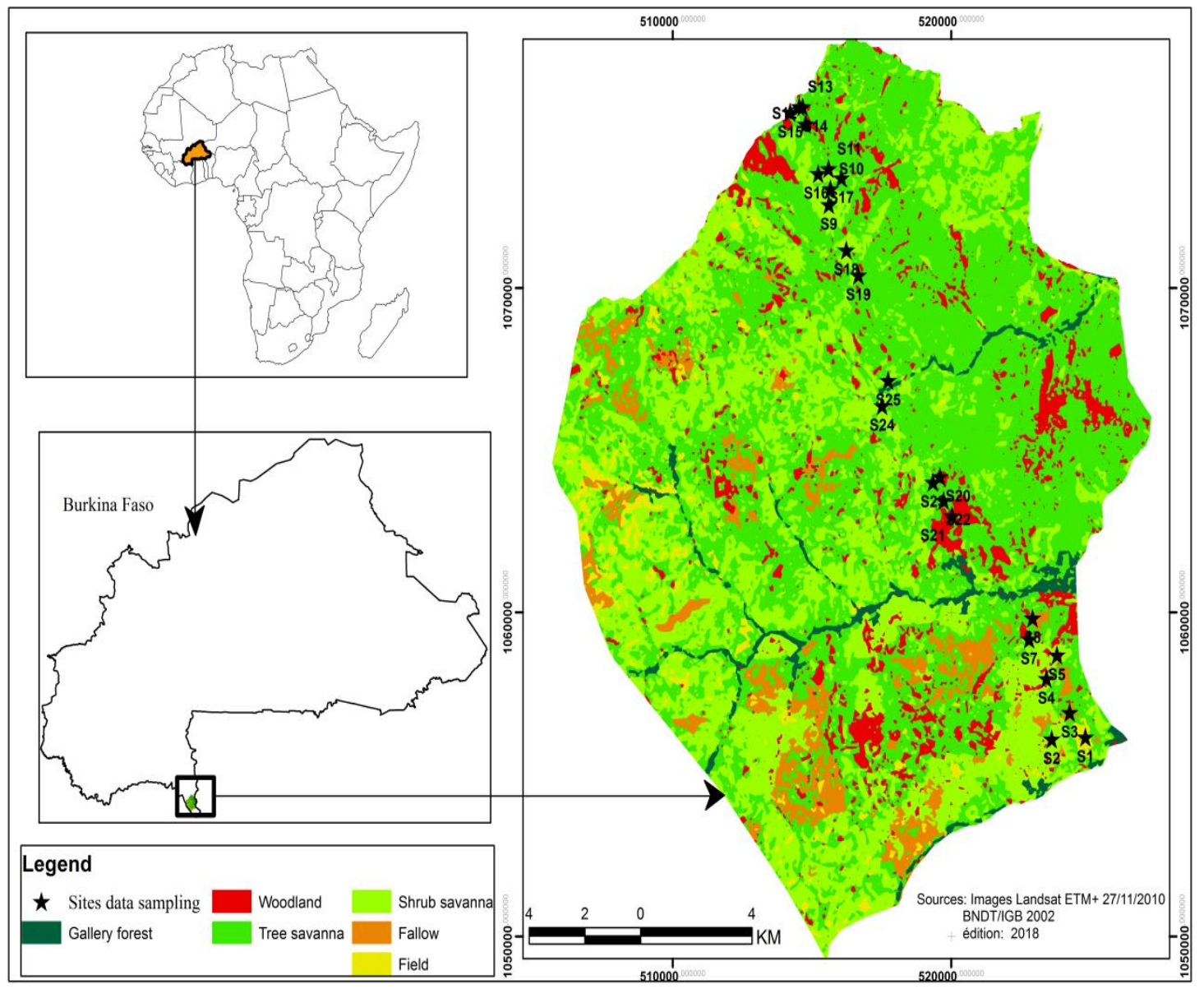

Figure 1: Land use types of Koulbi Forest. 


\section{J. T. YAMEOGO et al. / Int. J. Biol. Chem. Sci. 13(4): 2421-2432, 2019}

Table 1: Soil physical characteristics in the different land use types (depth 0-10 cm and 10-20 cm).

\begin{tabular}{|c|c|c|c|c|c|c|}
\hline \multirow[t]{3}{*}{ Land use type } & \multicolumn{6}{|c|}{ Physicochemical parameters } \\
\hline & \multicolumn{2}{|c|}{ Clay (g/kg) } & \multicolumn{2}{|c|}{ Silt (g/kg) } & \multicolumn{2}{|c|}{ Sand $(\mathrm{g} / \mathrm{kg})$} \\
\hline & $0-10 \mathrm{~cm}$ & $10-20 \mathrm{~cm}$ & $0-10 \mathrm{~cm}$ & $10-20 \mathrm{~cm}$ & $0-10 \mathrm{~cm}$ & $10-20 \mathrm{~cm}$ \\
\hline Woodland & $241.83^{\mathrm{a}}$ & $294.10^{\mathrm{a}}$ & $261.40^{\mathrm{ab}}$ & $228.77^{\mathrm{ab}}$ & $496.77^{\mathrm{bc}}$ & $477.13^{c}$ \\
\hline Tree savanna & $249.03^{\mathrm{a}}$ & $292.17^{\mathrm{a}}$ & $309.82^{\mathrm{a}}$ & $276.46^{\mathrm{a}}$ & $441.15^{\mathrm{c}}$ & $431.37^{\mathrm{bc}}$ \\
\hline Shrub savanna & $149.49^{\mathrm{ab}}$ & $196.08^{\mathrm{ab}}$ & $230.41^{\mathrm{ab}}$ & $159.33^{\mathrm{bc}}$ & $620.10^{\mathrm{ab}}$ & $644.60^{\mathrm{ab}}$ \\
\hline Field/Fallow & $58.80^{\mathrm{b}}$ & $3.92^{\mathrm{b}}$ & $152.00^{\mathrm{b}}$ & $11.77^{\mathrm{c}}$ & $789.20^{\mathrm{a}}$ & $833.30^{\mathrm{a}}$ \\
\hline $\mathrm{F}$ & 4.62 & 4.50 & 3.86 & 10.91 & 6.45 & 8.27 \\
\hline $\mathrm{p}$ & 0.01 & 0.01 & 0.02 & $<0.01$ & $<0.01$ & $<0.01$ \\
\hline
\end{tabular}

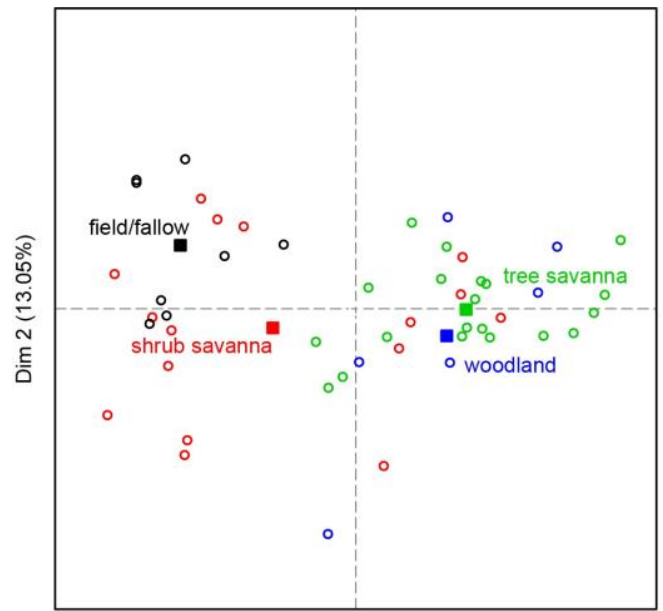

$\operatorname{Dim} 1(53.92 \%)$

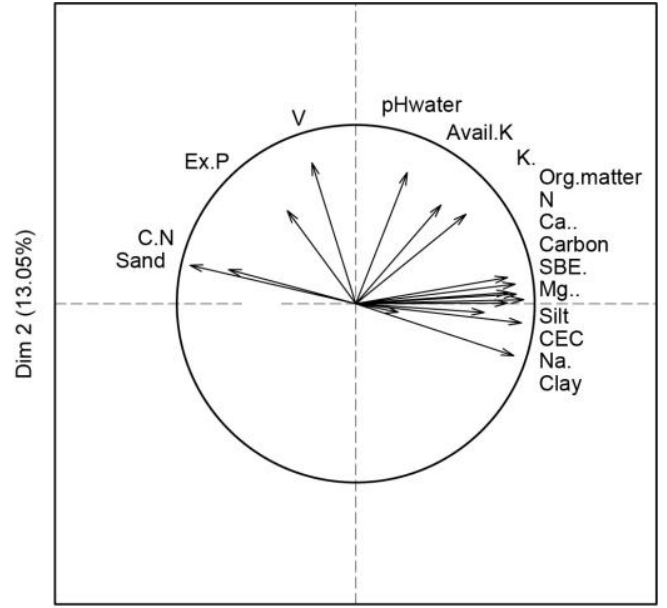

$\operatorname{Dim} 1(53.92 \%)$

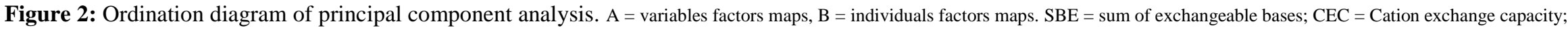
$\mathrm{V}=$ Rate of saturation, Avail- $\mathrm{K}=$ Available potassium, Exc- $\mathrm{P}=$ Exchangeable phosphorus 
Table 2: Soil physicochemical characteristics in 0-10 cm depth.

\begin{tabular}{|c|c|c|c|c|c|c|c|c|c|c|c|c|c|c|}
\hline \multirow[t]{2}{*}{ Land-use types } & \multicolumn{14}{|c|}{ Chemical parameters } \\
\hline & $\begin{array}{l}\mathrm{pH} \\
\text { water }\end{array}$ & $\begin{array}{l}\text { C } \\
(\mathrm{g} / \mathrm{kg})\end{array}$ & $\begin{array}{l}\mathrm{OM} \\
(\mathrm{g} / \mathrm{kg})\end{array}$ & $\begin{array}{l}\mathrm{N} \\
(\mathrm{g} / \mathrm{kg})\end{array}$ & $\mathrm{C} / \mathrm{N}$ & $\begin{array}{l}\text { Exc-P } \\
(\mathrm{mg} / \mathrm{kg})\end{array}$ & $\begin{array}{l}\text { Avail.K } \\
(\mathrm{mg} / \mathrm{k})\end{array}$ & $\begin{array}{l}\mathrm{Ca}^{2+} \\
(\mathrm{Cmol}+/ \mathrm{kg})\end{array}$ & $\begin{array}{l}\mathrm{Mg}^{2+} \\
\left(\mathrm{Cmol}^{+} / \mathrm{kg}\right)\end{array}$ & $\begin{array}{ll}\mathrm{K}^{+} & \left(\mathrm{Cmol}^{+} /\right. \\
\mathrm{kg}) & \\
\end{array}$ & $\begin{array}{l}\mathrm{Na}^{+}\left(\mathrm{Cmol}^{+} /\right. \\
\mathrm{kg})\end{array}$ & $\begin{array}{l}\text { SBE } \\
\left(\mathrm{Cmol}^{+} / \mathrm{kg}\right)\end{array}$ & $\begin{array}{l}\text { CEC } \\
\left(\mathrm{Cmol}^{+} / \mathrm{kg}\right)\end{array}$ & $\mathrm{V}(\%)$ \\
\hline Woodland & 6.72 & $16.31^{\mathrm{a}}$ & $28.11^{\mathrm{a}}$ & $1.44^{\mathrm{a}}$ & $11.42^{\mathrm{b}}$ & 1.29 & $155.90^{\mathrm{a}}$ & $15.65^{\mathrm{a}}$ & $3.94^{\mathrm{a}}$ & $0.42^{\mathrm{a}}$ & 0.03 & $20.04^{\mathrm{a}}$ & $22.17^{\mathrm{a}}$ & 90.64 \\
\hline Tree savanna & 6.86 & $16.17^{\mathrm{a}}$ & $27.87^{\mathrm{a}}$ & $1.26^{\mathrm{a}}$ & $12.78^{\mathrm{b}}$ & 0.81 & $148.30^{\mathrm{a}}$ & $14.45^{\mathrm{a}}$ & $4.95^{\mathrm{a}}$ & $0.28^{\mathrm{ab}}$ & 0.07 & $19.64^{\mathrm{a}}$ & $21.18^{\mathrm{a}}$ & 93.02 \\
\hline Shrub savanna & 6.61 & $11 .{ }^{17 \mathrm{ab}}$ & $19.94^{\mathrm{ab}}$ & $0.72^{\mathrm{b}}$ & $15.92^{\mathrm{a}}$ & 0.92 & $89.14^{\mathrm{b}}$ & $6.19^{\mathrm{ab}}$ & $1.50^{\mathrm{b}}$ & $0.23^{\mathrm{b}}$ & 0.08 & $8.00^{\mathrm{ab}}$ & $9.39^{\mathrm{ab}}$ & 90.42 \\
\hline Field/Fallow & 6.68 & $7.74^{\mathrm{b}}$ & $1.30^{\mathrm{b}}$ & $0.51^{\mathrm{b}}$ & $15.46^{\mathrm{a}}$ & 4.38 & $83.97^{\mathrm{b}}$ & $2.74^{\mathrm{b}}$ & $0.31^{\mathrm{b}}$ & $0.18^{\mathrm{b}}$ & 0.02 & $3.26^{\mathrm{b}}$ & $3.09^{\mathrm{b}}$ & 94.35 \\
\hline $\mathbf{F}$ & 1.38 & 10.30 & 9.66 & 18.78 & 12.65 & 2.10 & 5.01 & 7.17 & 4.66 & 3.83 & 0.47 & 7.59 & 7.37 & 0.14 \\
\hline $\mathbf{p}$ & 0.27 & $<0.01$ & $<0.01$ & $<0.01$ & $<0.01$ & 0.13 & $<0.01$ & $<0.01$ & 0.01 & 0.02 & 0.71 & $<0.01$ & $<0.01$ & 0.94 \\
\hline
\end{tabular}

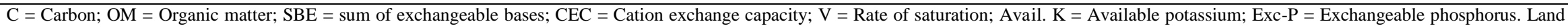
use types with the same letter in the same column are not statistically different at $p=0.05$ with Fisher LSD test. 
Table 3: Soil physicochemical characteristics in 10-20 cm depth.

\begin{tabular}{|c|c|c|c|c|c|c|c|c|c|c|c|c|c|c|}
\hline \multirow[t]{2}{*}{ Land-use types } & \multicolumn{14}{|c|}{ Chemical parameters } \\
\hline & $\begin{array}{l}\mathrm{pH} \\
\text { water }\end{array}$ & $\begin{array}{l}\text { C } \\
(\mathrm{g} / \mathrm{kg})\end{array}$ & $\begin{array}{l}\mathrm{OM} \\
(\mathrm{g} / \mathrm{kg})\end{array}$ & $\mathrm{N}(\mathrm{g} / \mathrm{kg})$ & $\mathrm{C} / \mathrm{N}$ & $\begin{array}{l}\text { Exc-P } \\
(\mathrm{mg} / \mathrm{kg})\end{array}$ & $\begin{array}{l}\text { Avail. } \\
\mathrm{K} \\
(\mathrm{mg} / \mathrm{k})\end{array}$ & $\begin{array}{l}\mathrm{Ca}^{2+} \\
\left(\mathrm{Cmol}^{+} /\right. \\
\mathrm{kg})\end{array}$ & $\begin{array}{l}\mathrm{Mg}^{2+} \\
\left(\mathrm{Cmol}^{+} /\right. \\
\mathrm{kg})\end{array}$ & $\begin{array}{l}\mathrm{K}^{+} \\
\left(\mathrm{Cmol}^{+} /\right. \\
\mathrm{kg})\end{array}$ & $\begin{array}{l}\mathrm{Na}^{+} \\
\left(\mathrm{Cmol}^{+} /\right. \\
\mathrm{kg})\end{array}$ & $\begin{array}{l}\mathrm{SBE} \\
\left(\mathrm{Cmol}^{+} /\right. \\
\mathrm{kg})\end{array}$ & $\begin{array}{l}\mathrm{CEC} \\
\left(\mathrm{Cmol}^{+} /\right. \\
\mathrm{kg})\end{array}$ & $\mathrm{V}(\%)$ \\
\hline Woodland & 5.96 & $11.05^{\mathrm{ab}}$ & $18.78^{\mathrm{a}}$ & $0.95^{\mathrm{a}}$ & $11.53^{b}$ & 0.50 & 54.53 & $11.28^{\mathrm{ab}}$ & $3.34^{\mathrm{ab}}$ & $0.161^{\mathrm{ab}}$ & 0.04 & $14.82^{\mathrm{a}}$ & $20.78^{\mathrm{a}}$ & 70.07 \\
\hline Tree savanna & 6.56 & $12.72^{\mathrm{a}}$ & $23.36^{\mathrm{a}}$ & $1.01^{\mathrm{a}}$ & $12.75^{\mathrm{b}}$ & 0.36 & 70.45 & $13.34^{\mathrm{a}}$ & $3.95^{\mathrm{a}}$ & $0.218^{\mathrm{a}}$ & 0.13 & $17.63^{\mathrm{a}}$ & $20.13^{\mathrm{a}}$ & 86.64 \\
\hline Shrub savanna & 6.29 & $10.59^{\mathrm{ab}}$ & $18.86^{\mathrm{ab}}$ & $0.70^{\mathrm{ab}}$ & $15.99^{\mathrm{ab}}$ & 0.45 & 49.92 & $5.01^{\mathrm{b}}$ & $1.49^{\mathrm{bc}}$ & $0.122^{\mathrm{ab}}$ & 0.19 & $6.81^{b}$ & $8.86^{\mathrm{b}}$ & 87.01 \\
\hline Field/Fallow & 6.59 & $6.44^{\mathrm{b}}$ & $10.90^{\mathrm{b}}$ & $0.36^{\mathrm{b}}$ & $18.33^{\mathrm{a}}$ & 3.96 & 40.42 & $2.94^{\mathrm{b}}$ & $0.25^{\mathrm{c}}$ & $0.13^{b}$ & 0.04 & $3.36^{\mathrm{b}}$ & $6.17^{b}$ & 78.12 \\
\hline $\mathbf{F}$ & 3.05 & 4.79 & 6.75 & 6.78 & 8.51 & 2.07 & 3.10 & 4.82 & 7.47 & 3.27 & 0.36 & 5.34 & 4.63 & 0.43 \\
\hline $\mathbf{p}$ & 0.05 & 0.01 & $<0.01$ & $<0.01$ & $<0.01$ & 0.14 & 0.05 & 0.01 & $<0.01$ & 0.04 & 0.78 & $<0.01$ & 0.01 & 0.73 \\
\hline
\end{tabular}

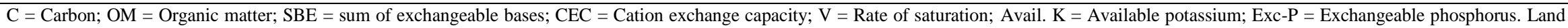
use types with the same letter in the same line are not statistically different at $\mathrm{p}=0.05$ with Fisher (LSD) test. 

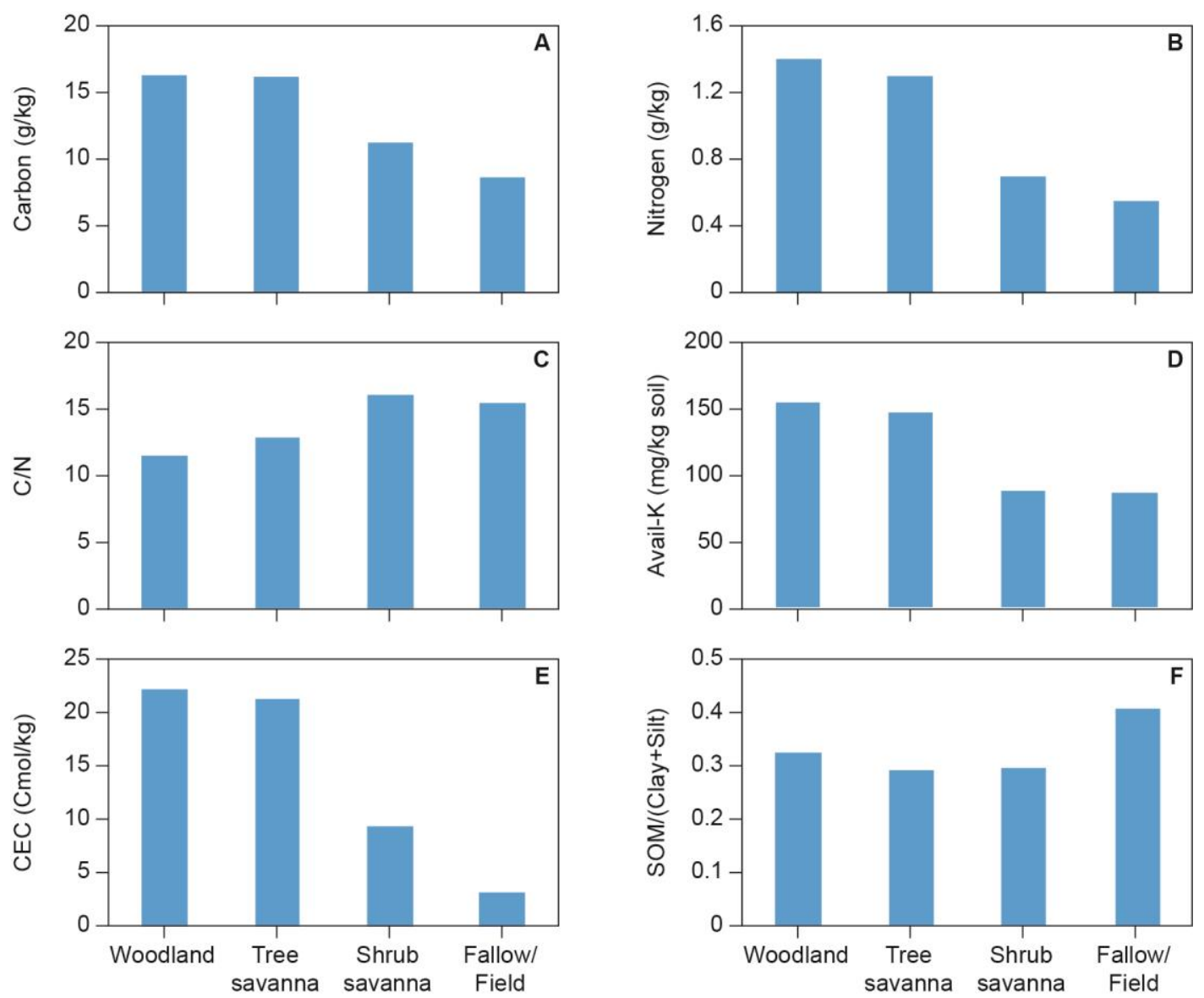

Figure 3: Some of the possible degradation indicators from 0-10 cm vs. land use. (A) Carbon, (B) Nitrogen, (C) C/N ratio, (D) Available potassium, (E) Soil cation exchange (CEC) capacity, (F) Soil organic matter (SOM)/( Clay+ silt) ratio. Parameters that are overlapping with (or strongly correlated to) some of the shown parameters (Organic matter and SEB) have been excluded from the graphics.

\section{DISCUSSION}

The idea of ranking $\mathrm{K}$ and use as a scale of physicochemical indicators of degradation may be a step towards a generally accepted scale of degradation. Ranking of the land uses woodland, tree savanna, shrub savanna, and field/fallow in decreasing order, suggested here, was supported by the distribution of these land uses in the PCA. Actually, the ranking of these land uses according to tree density or vegetation biomass would have been the same. A higher vegetation biomass in the areas investigated here can explain higher $\mathrm{C}$ and organic matter content in tree savanna and woodland compared to field/fallow. According to $\mathrm{Li}$ et al. (2013), the higher input of organic matter and nutrients through litter fall affects soil organic matter positively, and has been shown to be a good indicator of soil nutrient supply, amelioration of soil properties, and prevention of soil erosion (Nave et al., 2010). Trees have the potential to influence soil properties through many pathways, including speciesspecific effects on quality and quantity of leaf and root litter (Talkner et al., 2009; Kagambèga et al., 2011; Wang et al., 2011). The lowest values of SOM, found in field/fallow, could be linked to a lack of trees (Tebebu et al., 2017). This is supported by the observation that conversion of forests to other land uses leads to a significant decrease of soil fertility (Kassa et al., 2017; Gao et al., 2017). Consequently, in non-fertilized areas it seems logical to measure land degradation on a scale of trees per area unit or biomass per area unit 
seen in relation to optimal vegetation type under present climate conditions.

The succession of vegetation is often accompanied by changes in soil properties (e.g. Li et al., 2013). On the other hand, soil provides essential nutrients for vegetation growth and development, and this in turn may drive some of the changes in soil formation and modification creating an interactive soilvegetation feedback (Kardol et al., 2006; Li et al., 2013). The highly positive correlation between the parameters N, CEC, SBE, C, $\mathrm{SOM}, \mathrm{Mg}$, clay and silt suggest that these factors may be used as indicators of tree savanna and woodland. Similarly, the highly negative correlation between $\mathrm{C} / \mathrm{N}$-ratios and high content of sand with most other chemical parameters makes these parameters possible indicators of field and fallow. If the land uses investigated in this paper represent a degradation gradient, the mentioned factors are candidates to be degradation indicators.

Woodland, tree savanna and shrub savanna revealed the highest values of CEC and SBE. They were closely and positively correlated to the first axis in the PCA and show a steep dependence on land uses. This could be explained by the litter fall from the trees as e.g. Zombré (2006) reported that litter increases the organic stock and the CEC, which would oppose the lixiviation of cations. Consequently, based on our results CEC seems to be a good degradation indicator. SBE would also be a good indicator, but using both of them does not make sense as the two parameters overlap, and they are closely correlated.

According to our results, high values of $\mathrm{C} / \mathrm{N}$ can be used as an indicator of field/fallow, and therefore a rather high degree of soil degradation. Low $\mathrm{C} / \mathrm{N}$ values seem to indicate woodland and tree savanna with relatively high tree density and much plant litters and consequently low degradation. In fact, litter with slower decomposition rate contained more substances that are difficult to decompose (e.g., cellulose and lignin), and low nutrient elements like nitrogen, resulting in high $\mathrm{C} / \mathrm{N}$ (Duan et al., 2017). The residual soil organic matter in Field/fallow is probably constitutes of cellulose and lignin. According to Michael \& Joshua (2003) nitrogen controls the early phase of organic matter decomposition and lignin controls the later phase.

The result that nitrogen content followed the organic matter could be due to high mineralization activity of organic matter in woodland and tree savanna (Moussa et al., 2015, Alberti et al., 2015). In fact, soils with high $\mathrm{N}$ mineralization potential tend to be inherently fertile, while soils with low $\mathrm{N}$ mineralization potential tend to be less fertile and require greater agricultural inputs. Otherwise, intensive cultivation depletes soil organic matter, causing a significant decline in the potential for $\mathrm{N}$ mineralization processes to provide plant available $\mathrm{N}$. This could explain the low content of soil nitrogen in field and fallow. Koulibaly et al. (2014) found similar results in the ferruginous and ferralitics soil of Burkina Faso.

The high content of sand in fields and fallows show that a constant plant cover and biomass observed in tree savanna and woodland protect soil against erosion and soil fine particles lixiviation. In fact, reducing cover exposes the soil to wind and water erosion (Jiang et al., 2017; Quijano et al., 2017). Furthermore, some authors reported that manual cultivation mainly based on consistent turn up of soil leads to loss of clay and silt from the topsoil (De Rouw and Rajot, 2004; Moussa et al., 2015)

\section{Conclusion}

Changes in land use significantly affected soil properties. Field/fallow were characterised by low content of clay and silt and low soil fertility as reflected by low SOM, $\mathrm{N}$, avail-K, SBE and CEC. The results showed how continuous cultivation and deforestations affect soil properties and suggest that longer fallow periods are necessary to ensure good soil quality. The results presented here support the idea of using land use as a proxy for a degradation scale, which is suggested to be vegetative biomass seen in relation to the optimal vegetation type in the area. Vegetative biomass can be very laborious to measure, and therefore good indicators are advantageous. Based on our results sand and high $\mathrm{C} / \mathrm{N}$ were 
indicators of degradation. The best indicators of low degradation was CEC, but high $\mathrm{N}$, avail-K and $\mathrm{C}$ content seem also to be good candidates.

\section{COMPETING INTERESTS}

The authors declare that they have no competing interests.

\section{AUTHORS' CONTRIBUTIONS}

JTY was the main responsible for sampling, soil analysis, data analysis and writing it all together. JAA developed the idea together with JTY, supervised soil analysis and contributed significantly to writing the article. AML contributed to statistical and multivariate analysis, verification of data and writing of the article. ZS contributed cartography the forest, data sampling and writing of the article. BMM contributed to soil analysis, statistical analysis and writing of the article. IS contributed to writing of the article.

\section{ACKNOWLEDGEMENTS}

Funded thanks to the UNDESERT project (EU FP7 243906) 'Understanding and combating desertification to mitigate its impact on ecosystem services' funded by the European Commission.

\section{REFERENCES}

Alberti G, Vicca S, Inglima I, BelelliMarchesini L, Genesio L, Miglietta F, Marjanovic H, Martinez C, Matteucci G, D'Andrea E, Peressotti A, Petrella F, Rodeghiero M, Cotrufo MF. 2015. Soil C:N stoichiometry controls carbon sink partitioning between above-ground tree biomass and soil organic matter in high fertility forests. Forest-Biogeosciences and Forestry, 8: 195-20. DOI: 10.3832/ifor1196-008.

Bremner JM. 1965. Total nitrogen. Part 2: Chemical and Microbiological Properties. In Methods of Soil Analysis. American Society of Agronomy. Inc. Black CA: Madison WI; 1149-1178.

BUNASOLS. 1987. Méthodes d'Analyse Physique, Chimique des Sols, Eaux, Plantes. Document Technique 3, BUNASOLS, Ouagadougou.
De Rouw A, Rajot JL. 2004. Soil organic matter, surface crusting and erosion in Sahelian farming systems based on manuring or fallowing. Agriculture, Ecosystems and Environment, 104: 263276. DOI: $10.1016 /$ j.agee.2003.12.020.

Dimobe K, Goetze D, Ouédraogo A, Forkuor G, Wala K, Porembski S, Thiombiano A. 2017. Spatio-temporal dynamics in land use and habitat fragmentation within a protected area dedicated to tourism in a Sudanian savanna of West Africa. Journal of Landscape Ecology, 10: 7595. DOI: 10.1515/jlecol-2017-0011

Duan H, Wang L, Zhang Y, Fu X, Tsang Y, $\mathrm{Wu}$ J, Le Y. 2017. Variable decomposition of two plant litters and their effects on the carbon sequestration ability of wetland soil in the Yangtze River. Geoderma. DOI: 10.1016/j.geoderma.2017.10.050.

FAO. 2004. Guiding Principles for the Quantitative Assessment of Soil Degradation. FAO: Rome.

Gbedahi OLC, Biaou SSH, Mama A, Gouwakinnou GN, Yorou NS. 2019. Dynamique du couvert végétal à Bassila au nord Bénin pendant et après la mise en œuvre d'un projet d'aménagement forestier. International Journal of Biological and Chemical Sciences, 13(1): $\quad 311-324 . \quad$ DOI: https://dx.doi.org/10.4314/ijbcs.v13i1.25

Febles JM, Tolon A, Vega MB. 2009. Edaphic indicators for assessment of soil erosion in Karst region, province of Havana, Cuba. Land Degradation \& Development, 20: 522-534. DOI: 10.1002/ldr.929.

Fontes J, Guinko S. 1995. Carte de la Végétation et de l'Occupation du Sol du Burkina Faso. Note explicative, Ministère de la Coopération Française, Toulouse.

Gao X, Meng T, Zhao X. 2017. Variations of soil organic carbon following land use change on Deep-Loess Hillslopes in China. Land Degradation \& Development, 28: 1902-1912. DOI: 10.1002/ldr.2693. 
Jiang XJ, Liu W, Wu J, Wang P, Liu C, Yuan Z-Q. 2017. Land degradation controlled and mitigated by rubber-based agroforestry systems through optimizing soil physical conditions and water supply mechanisms: A case study in Xishuangbanna, China. Land Degradation \& Development, 28: 22772289. DOI: $10.1002 / \mathrm{ldr} .2757$.

Kaboré SA, Schumann K, Hien M, Lykke AM, Hahn K, Nacro HB. 2015. Stratégies d'adaptation à la réduction des services écosystémiques: cas des potentialités de substitution de trois espèces forestières dans le Sud-Ouest du Burkina Faso. International Journal of Biological and Chemical Sciences, 9: 1194-1208.

Kagambèga FW, Traoré S, Thiombiano $\mathrm{T}$, Boussim JI. 2011. Impact de trois techniques de restauration des sols sur la survie et la croissance de trois espèces ligneuses sur les 'zipellés' au Burkina Faso. International Journal of Biological and Chemical Sciences, 5: 901-914.

Kassa H, Dondeyne S, Poesen J, Frankl A, Nyssen J. 2017. Transition from forestbased to cereal-based agricultural Systems: A review of the drivers of land use change and degradation in southwest Ethiopia. Land Degradation \& Development, 28: 431-449. DOI: 10.1002/ldr.2575.

Khaledian Y, Kiani F, Ebrahimi S, Brevik EC, Aitkenhead-Peterson J. 2017. Assessment and monitoring of soil degradation during land use change using multivariate analysis. Land Degradation \& Development, 28: 128141. DOI: $10.1002 / \mathrm{ldr} .2541$.

Kardol P, Martijn-Bezemer T, Van Der Putten WH. 2006. Temporal variation in plantsoil feedback controls succession. Ecology Letters, 9: 1080-1088. DOI: 10.1111/j.1461-0248.2006.00953.x.

Koulibaly B, Traoré O, Dakuo D, Lalsaga R, Lompo F, Zombré PN. 2014. Acidification des sols ferrugineux et ferralitiques dans les systèmes de production cotonnière au Burkina Faso. International Journal of Biological and
Chemical Sciences, 8: 2879-2890. DOI: 10.4314/ijbcs.v8i6.44.

Li YQ, Brandle J, Awada T, Chen YP, Han JJ, Zhang FX, Zhang F, Luo Y. 2013. Accumulation of carbon and nitrogen in the plant-soil system after afforestation of active sand dunes in China's Horqin Sandy Land. Agriculture, Ecosystems \& Environment, 177: 75-84. DOI: 10.1016/j.agee.2013.06.007.

Loveland PJ, Whalley WR. 1991. Particle size analysis. in Soil Analysis: Physical Methods, Smith KA, Mullis CE (ed). Marcel Dekker Inc: New York; 271-328.

Michael NW, Joshua PS. 2003. Interactions between carbon and nitrogen mineralization and soil organic matter in chemistry in arctic tundra soils. Ecosystems, 6: 129-143. DOI: 10.1007/s10021-002-0124-6.

Moussa BM, Diouf A, Abdourahamane SI, Jangorzo NS, Mahamane A, Axelsen JA, Ambouta J-MK. 2015. Soil physicochemical characteristics under different ecosystems in Western Niger. International Journal of Current Microbiology and Applied Sciences, 4: 375-383.

Mylavarapu R. 2015. Walkley-Black Method. www.clemson.edu/sera6/WalkleyBlackF inal052711.doc.

Nave LE, Vance ED, Swanston CW, Curtis PS. 2010. Harvest impact on soil carbon storage in temperate forests. Forest Ecology and Management, 259: 857-866. DOI: $10.1016 /$ j.foreco.2009.12.009.

Quiroga A, Funaro D, Noellemeyer E, Peinemann N. 2006. Barley yield response to soil organic matter and texture in the Pampas of Argentina. Soil \& Tillage Research, 90: 63-68. DOI: 10.1016/j.still.2005.08.019.

Quijano L, Van Oost, K, Nadeau E, Gaspar L, Navas A. 2017. Modelling the effect of land management changes on soil organic carbon stocks in a Mediterranean cultivated field. Land Degradation \& Development, 28: 515-523. DOI: 10.1002/ldr.2637.

R Development Core Team. 2010. A Language and Environment for 
Statistical Computing. R Foundation for

Statistical Computing (computer software), Vienna. Available from: http://www.R-project.org.

van Reeuwijk LP. 2002. Procedures for Soil Analysis (Sixth ed Technical Report 9). ISRIC-Word Soil Information: Wageningen.

Sahilemedhin S, Taye B. 2000. Procedures for soil and plant analysis. National Soil Research Center, Ethiopian Agricultural Research Organization, Technical Paper 74. Addis Ababa.

Schmidt M, Zizka G. 2014. Plant species associated with different levels of species richness and of vegetation cover as indicators of desertification in Burkina Faso (West Africa). Flora et Vegetatio Sudano-Sambesica, 17: 3-8. DOI: 10.21248/fvss.17.22.

Talkner U, Jansen M, Beese FO. 2009. Soil phosphorus status and turnover in central-European beech forest ecosystems with differing tree species diversity. European Journal of Soil Science, $\quad$ 60: $338-346$. DOI:10.1111/j.1365-2389.2008.01117.x.

Tankoano B, Sanon Z, Hien M, Dibi NH, Yaméogo JT, Somda I. 2016. Pression anthropique et dynamique végétale dans la Forêt Classée de Tiogoau Burkina
Faso: Apport de la télédétection. Tropicultura, 34: 193-207.

Tebebu TY, Bayabil HK, Stoof CR, Giri SK, Gessess AA, Tilahun SA, Steenhuis TS. 2017. Characterization of degraded soils in the humid Ethiopian highlands. Land Degradation \& Development, 28: 1891 1901. DOI: 10.1002/ldr.2687.

Traoré S, Ouattara K, Ilstedt U, Schmidt M, Thiombiano A, Malmer A, Nyberg G. 2015. Effect of land degradation on carbon and nitrogen pools in two soil types of a simi-arid landscape in West Africa. Geoderma, 241-242: 330-338. DOI: 10.1016/j.geoderma.2014.11.027.

Wang Q, Wang S, Yu X. 2011. Decline of soil fertility during forest conversion of secondary forest to Chinese fir plantation in subtropical China. Land Degradation \& Development, 22: 444-452. DOI: 10.1002/ldr.1030.

Zombré NP. 2006. Variation de l'activité biologique dans les zipella (sols nus) en zone subsahélienne du Burkina Faso et impact de la technique du zaï (techniques des poquets). Biotechnology, Agronomy, Society and Environment, 10: 139-148. 